\title{
Evidence of Colonization of Man-made Ecotopes by Triatoma dimidiata (Latreille, 1811) in Costa Rica
}

\author{
Rodrigo Zeledón+ ${ }^{+}$, Víctor M Montenegro, Oswaldo Zeledón
}

\author{
Escuela de Medicina Veterinaria, Universidad Nacional, Apartado Postal 86, Heredia, Costa Rica
}

Triatoma dimidiata adults have been frequently found, during the last five years, in a dog kennel and a chicken coop, in the back yard of a well-built house, $15 \mathrm{~km}$ from San José, the capital of Costa Rica. In the chicken coop nymphs were also found. Two of the 11 dogs from the kennel were serologically positive for Trypanosoma cruzi infection. The inhabitants of the house, three adults and two children, were negative. This type of colonization by the insect, which is attracted to lights, is becoming common in old and new settlements, with different degrees of success, a fact with epidemiological implications and great relevance in the control strategies that can be applied.

Key words: colonization - Triatoma dimidiata - man-made ecotopes - Costa Rica

Triatoma dimidiata, the main vector of Chagas disease in Costa Rica, can be found in human dwellings and in wild habitats (Zeledón et al. 1970b). The insect is distributed from the middle of Mexico to northern Peru with its most eastern location in northwestern Venezuela (Carcavallo et al. 1999).

Inside houses with poor sanitary conditions, the insects are located mainly on walls of bedrooms, close to beds, in general no more than $1 \mathrm{~m}$ above the ground. They are also common behind pictures or wall papers, in hanging garments or in accumulated objects of different kinds, but usually their colonies do not surpass one or two dozen individuals. In the surroundings of the houses, bugs are found hidden in all sorts of stored objects, particularly in fire wood piles and in chicken coops (Zeledón et al. 1975). They are also associated with houses with dirt floors where the nymphs camouflage themselves by covering their bodies with debris, a phenomenon with epidemiological implications (Zeledón et al. 1969, Starr et al. 1991).

In some Central American countries and in Ecuador, $T$. dimidiata exhibits a tendency to become urban or periurban by invading some cities. It also has been found under sylvatic conditions especially in association with wild animal nests, such as opossums, in abandoned lots or in the bush surrounding areas close to villages or towns, and also in most

\footnotetext{
${ }^{+}$Corresponding author. Fax: +506-225.3633. E-mail: rzeledon@sol.racsa.co.cr

Received 27 November 2000

Accepted 8 March 2001
}

national parks and other conservation areas of Costa Rica either in dry or rainy forests (Zeledón et al. 1973, Zeledón et al., unpublished observations). The frequent infection of opossums (Didelphis marsupialis) with Trypanosoma cruzi, the agent of Chagas disease, explains the high rates of infection of $T$. dimidiata with the parasite and the repeated finding of opossum blood in the intestine of bugs found in or around houses. This is a strong indication of the link that exists between the wild and domestic cycles of the parasite involving the same vector (Zeledón et al. 1970a, 1973). Furthermore, the attraction of the insect to electric lights has been a well known phenomenon for about 70 years (Campos 1931, Zeledón 1981). Passive transport of the insects to houses, particularly with firewood, is also possible (Zeledón et al. 1973).

Recently we had the opportunity to observe the colonization by wild specimens of $T$. dimidiata of at least one artificial ecotope in the back yard of a new, well-built house, in an area close to the town of Santa Ana (Province of San José), $15 \mathrm{~km}$ from the capital, where the bugs had been found before in poor dwellings of the neighborhood.

The house was constructed with brick and cement in June 1995 on an isolated lot of land measuring $1,630 \mathrm{~m}^{2}$. It is situated in the village of Río Oro, surrounded by gardens and a large yard. Both sides of the property are bordered by empty lots of land with dispersed vegetation whilst the boundary at the back is formed by the Uruca River canyon which is about $150 \mathrm{~m}$ deep and covered by secondary forest. The house has an open garage with an electric light towards the back yard that is kept on all night. 
On the right side of the back-yard, a chicken coop was constructed in 1995 measuring $2,6 \mathrm{~m}$ by $6 \mathrm{~m}$ and $2 \mathrm{~m}$ high for about 20 chickens. Next to the chicken coop is a storeroom measuring 2,6 m by $4 \mathrm{~m}$ and $2 \mathrm{~m}$ high.

On the left side of the back-yard at the edge of the canyon, at a distance of $13 \mathrm{~m}$ from the house, a dog kennel was built in April 1997 for about 15 dogs of various breeds. These animals have been used for reproduction purposes and as such the number of dogs can vary between 10 to 30 with an average of 15 . The kennel measures $6,5 \mathrm{~m}$ by $8 \mathrm{~m}$ and $3 \mathrm{~m}$ high with 10 cages $1 \mathrm{~m}$ by $4 \mathrm{~m}$ and $2 \mathrm{~m}$ high.

The first insect found appeared inside the house before the kennel was built. Since the completion of the kennel, about 25 adult insects have been found, one at a time, in the kennel. On some occasions they have been found alive and on others they have been killed by the dogs and therefore have appeared mutilated. They have always been noticed in the mornings when the cages are cleaned and the animals are fed. Generally the insects found were full of blood.

Eleven dogs were examined serologically by three different tests (ELISA, Polychaco; indirect hemagglutination, Bio-Merieux; and indirect immunoflorescence) and two were found positive in all tests, and one was positive in only one test (ELISA).

This situation prompted the owners, who are a couple of veterinarians, to search for insects in the chicken coop, and three nymphs and two adults were found. The feces of one of the adults, which was positive for $T$. cruzi, were used to infect five Balb/c mice. The strain (IDIM/CR/1997/Oswaldo/ T. cruzi) is now being maintained in the laboratory by periodic transfers, and it kills the mice after 15 days of infection producing numerous amastigote forms in the myocardium.

Opossums are frequent visitors to the property and one of them was captured by one of the dogs that was kept outside the kennel during the night.

The inhabitants of the house, three adults and two children (10 and 14 years old) were all serologically negative to the ELISA test and to the indirect hemagglutination test.

We have described here an example of a phenomenon that seems to occur frequently in different areas of the country in which wild T. dimidiata, widely distributed in the Costa Rican territory, is constantly invading artificial ecotopes in old and new settlements and with a partial or complete success in its domiciliation which is mediated by socioeconomic factors. If the bugs find the adequate places to thrive they might either do it on peridomestic sites, as in this case, or inside the household if its sanitary condition allows it. Animals such as chickens and dogs in their shelters are frequently the first victims visited and in the case of the latter they easily become infected with T. cruzi, due to their instinct of grabing the insects with the mouth and chewing them up, an infection mechanism much more effective than the classic one through a skin abrasion or by the eye conjunctiva as occurs in humans (Montenegro et al. manusc. in prep.).

These frequent visits of wild $T$. dimidiata adults, mainly attracted to lights at night, in different geographical locations, pose difficulties for the control of the insect. Thus, to achieve a long term control strategy we recommend adequate and permanent environmental management measures, based on the insect's behavior and designed to make thriving more difficult.

\section{ACKNOWLEDGEMENT}

To Miss Misha Johnson for valuable help and for the revision of the manuscript.

\section{REFERENCES}

Campos F 1931. La chinche sanguinófila Triatoma dimidiata Latr., y su amplia dispersión intraurbana. Peligros que entraña su propagación. Medios de combatirla. Rev Col Nac Vicente Rocafuerte 13: 107111.

Carcavallo RU, Curto de Casas SI, Sherlock IA, Galíndez Girón I, Jurberg J, Galvão C, Mena Segura C, Noireau F 1999. Geographic distribution and altilatitudinal dispersion. In RU Carcavallo, I Galíndez Girón, J Jurberg, H Lent (eds.), Atlas of Chagas' Disease Vectors in the Americas, Vol. III, Editora Fiocruz, Rio de Janeiro, p. 747-792.

Starr MD, Rojas JC, Zeledón R, Hird DW, Carpenter TE 1991. Chagas' disease: risk factors for house infestation by Triatoma dimidiata, the major vector of Trypanosoma cruzi in Costa Rica. Am J Epidemiol 133: 740-747.

Zeledón R 1981. El Triatoma dimidiata (Latreille, 1811) y su relación con la enfermedad de Chagas, Editorial Universidad Estatal a Distancia, Costa Rica, 146 pp.

Zeledón R, Solano G, Burstin L, Swartzwelder JC 1975. Epidemiological pattern of Chagas' disease in an endemic area of Costa Rica. Am J Trop Med Hyg 24: 214-225.

Zeledón R, Solano G, Sáenz G, Swartzwelder JC 1970a. Wild reservoirs of Trypanosoma cruzi with special mention of the opossum, Didelphis marsupialis, and its role in the epidemiology of Chagas' disease in an endemic area of Costa Rica. J Parasitol 56: 38.

Zeledón R, Solano G, Swartzwelder JC 1970b. Sources of blood for Triatoma dimidiata (Hemiptera, Reduviidae) in an endemic area of Chagas' disease in Costa Rica. J Parasitol 56: 102.

Zeledón R, Solano G, Zúñiga A, Swartzwelder JC 1973. Biology and ethology of Triatoma dimidiata (Latreille, 1811). III. Habitat and blood sources. $J$ Med Entomol 10: 363-370.

Zeledón R, Zúñiga A, Swartzwelder JC 1969. The camouflage of Triatoma dimidiata and the epidemiology of Chagas' disease in Costa Rica. Bol Chile Parasitol 24: 106-108. 